\title{
THE INFLUENCE OF CAREER ORIENTATIONS ON SUBJECTIVE WORK EXPERIENCES
}

Authors:

Melinde Coetzee ${ }^{1}$

Ziel Bergh ${ }^{1}$

Dries Schreuder ${ }^{1}$

\section{Affiliations:}

${ }^{1}$ Department of Industrial and Organisational

Psychology, University of

South Africa, South Africa

Correspondence to:

Melinde Coetzee

email:

coetzm1@unisa.ac.za

Postal address:

Department of Industrial and Organisational

Psychology, AJH vd Walt

Room 4-07, PO Box 392

UNISA, 0003, Pretoria,

South Africa

\section{Keywords:}

entrepreneurial creativity; general management competence; pure challenge or competitiveness; service or dedication to a cause; technical or functional competence; life satisfaction; job or career satisfaction; happiness; work as a valuable activity

\section{Dates:}

Received: 08 Feb. 2010

Accepted: 17 Aug. 2010

Published: 19 Nov. 2010

How to cite this article: Coetzee, M., Bergh, Z., \& Schreuder, D. (2010). The influence of career orientations on subjective work experiences. $S A$ Journal of Human Resource Management/SA Tydskrif vir Menslikehulpbronbestuur, 8(1), Art. \#279, 13 pages. DOI: 10.4102/sajhrm.v8i1.279

This article is available at: http://www.sajhrm.co.za

(C) 2010. The Authors. Licensee: OpenJournals Publishing. This work is licensed under the Creative Commons Attribution License.

\section{ABSTRACT}

Orientation: In an increasingly turbulent business context in which people are less dependent on organisational career arrangements and have greater agency in career decisions, organisations have come to pay increasing attention to retaining valuable talented managerial potential.

Research purpose: The study empirically assessed the causal influence of individuals' career orientations on their perceived life satisfaction, job or career satisfaction, sense of happiness and their perceptions of work as a valuable activity as aspects of their subjective work experiences.

Motivation for study: From an organisational perspective, research on individuals' inner definitions of career success and satisfaction is needed to guide current selection, placement, development, reward and retention practices.

Research design, approach and method: A quantitative survey was conducted on a random sample of 2997 participants at predominantly managerial and supervisory level in the service industry. The measuring instruments consisted of an adapted five-factor career orientations model of the Career Orientations Inventory and a 4-item global subjective work experiences scale. Structural equation modelling (SEM) was conducted to achieve the aim of the study.

Main findings/results: Statistically significant causal relationships were observed between the career orientations and subjective work experiences variables.

Practical implications: Individuals' career orientations influence their general sense of life and job or career satisfaction, happiness and perceptions of work as a valuable activity. Organisations concerned with the retention of staff need to find a way of aligning individuals' career needs and motives with the goals and aspirations of the organisation.

Contribution/value-add: The research confirms the need for assessing the inner career orientations of employees as these provide valuable information regarding the motives and values driving individuals' career decision making and subjective experiences of their working lives.

\section{INTRODUCTION}

\section{Key focus of and background to the study}

In an increasingly turbulent business context in which people are less dependent on organisational career arrangements because they experience more frequent career transitions, people have greater agency in career decisions and must ensure that they are able and adaptable learners; organisations have come to pay increasing attention to attracting, engaging and retaining key employees and potential organisational leaders (Arthur, Khapova \& Wilderom, 2005; Baruch, 2004; Kock \& Burke, 2008). Moreover, the national drive to achieve employment equity has heightened the competition for talent and managerial potential amongst people from designated groups (Kotzé \& Roodt, 2005). Consequently, subjective career measures that emphasise psychological attributes and subjective work experiences (such as employees' life satisfaction), job and career satisfaction and happiness in the workplace have assumed greater significance in today's work environment (Brown, GeorgeCurran \& Smith, 2003; Ebberwein, Krieshok, Ulven \& Prosser, 2004; Judge, Bono, Erez \& Locke, 2005; Kokou \& Ierodiakono, 2007; Van Dam, 2004). Employees' subjective work experiences are also increasingly being assumed to be determinants of employee morale and the intention to stay or leave the organisation (Anastasiadou, 2007; Kokou \& Ierodiakonou, 2007; Martin \& Roodt, 2008).

As individuals start to take ownership of their careers, the focus on the subjective or inner career becomes increasingly more important than that of the more objective, organisationally defined career (Derr \& Briscoe, 2007; Hall, 1976). Whereas the internal career is a self-definition of career success as it is more subjective, long-term and stable and represents life goals as well as work goals, the external career is an organisational or professional definition of career success that is more short term, unpredictable and fast-changing (Derr \& Briscoe, 2007). Researchers such as Derr (1986), Driver (1982) and Schein $(1975 ; 1978)$ have extensively explored the internal career paradigm and found that people differ significantly in the way they think about their careers. Their research suggests that people's career choices and experiences of subjective career success and general satisfaction with their working lives are driven by a set of master career motives that seem to form part of the career self-concept or inner career orientation. These master motives act as a cognitive compass (Fugate, Kinicki \& Ashforth, 2004) that motivates and pulls people towards (or constrains them from) specific career choices and decisions (Schein, 1978, 1990).

Researchers in the careers field have stated in support of the foregoing that the attention given to individuals' inner definitions of career success (as defined by their career orientations), as a means of predicting employees' organisational commitment, job satisfaction, motivation and performance is a prominent trend in organisations today (Coetzee \& De Villiers, 2010; Havran, Visser \& Crous, 
2003; Kanye \& Crous, 2007; Lumley, 2010). Organisations that endeavour to retain valuable employees are therefore urged to provide incentives and career paths that are consistent with the career values, expectations and aspirations that underlie the career orientations of these employees (Coetzee \& Schreuder, 2009a; Järlström, 2000; Schein, 1996; Suutari \& Taka, 2004). If there is no fit between employees' inner career orientations and their job environment, the result may well be anxiety, stress, job and career dissatisfaction, unhappiness and high turnover (Coetzee \& Bergh, 2009; Feldman \& Bolino, 1996; Jiang \& Klein 2000; Jiang, Klein \& Balloun, 2001). From an organisation's perspective, research on career orientations is needed to guide current selection, placement, development, reward and retention practices (Ramakrishna \& Potosky, 2002).

The primary objective of the present study is to empirically assess whether people's career orientations significantly influence their subjective work experiences as explained by their general sense of life satisfaction, job or career satisfaction, happiness and perception of work as a valuable activity. Assessing the relationship between the inner career orientations of employees and their subjective experiences of their working lives may provide valuable information regarding the motives and values driving individuals' career decision making and turnover intentions. In this regard, research has indicated that level of pay, lack of career development opportunities, unmet needs due to a lack of person-organisation fit, lack of support from line manager and working conditions or job stress are some of the major push factors that lead to unwanted staff turnover (Aamodt, 2010; Marchington \& Wilkinson, 2008).

The next section of the article will create the context of the present study by means of a literature review after which the research design (which covers the research approach and method) will be elaborated on. This is followed by the presentation of the results and a discussion of the findings of the study. The article concludes with a brief synopsis of the main conclusions, implications for practice and recommendations for potential future research.

\section{Trends from the research literature \\ Career orientations}

Career orientations have been coined by Schein (1978) as career anchors. These career anchors denote a pattern of selfperceived talents and abilities, basic values and the evolved sense of motives and needs (as they pertain to the career), that influences a person's career-related decisions (Schein 1974, 1975, 1978, 1996). The conceptual model associated with Schein's (1978) career anchor or orientations theory is best understood in terms of individuals' career self-concept, which develops as a person gains life experience. As individuals are required to make choices related to their self-development, family or career, they may become more aware of the values and motives that govern the choices they make. In other words, an individual's career self-concept acts as a stabilising force such that when an important life (or career) choice needs to be made, there are certain concerns, needs or values that the individual will not give up (Schein, 1975).

Research by Schein $(1978,1990,1996)$ suggests that most people's career self-concepts (motives and values) are grounded in eight categories or anchors:

1. Autonomy or independence includes a person's need to be free of organisational constraints in order to pursue professional competence.
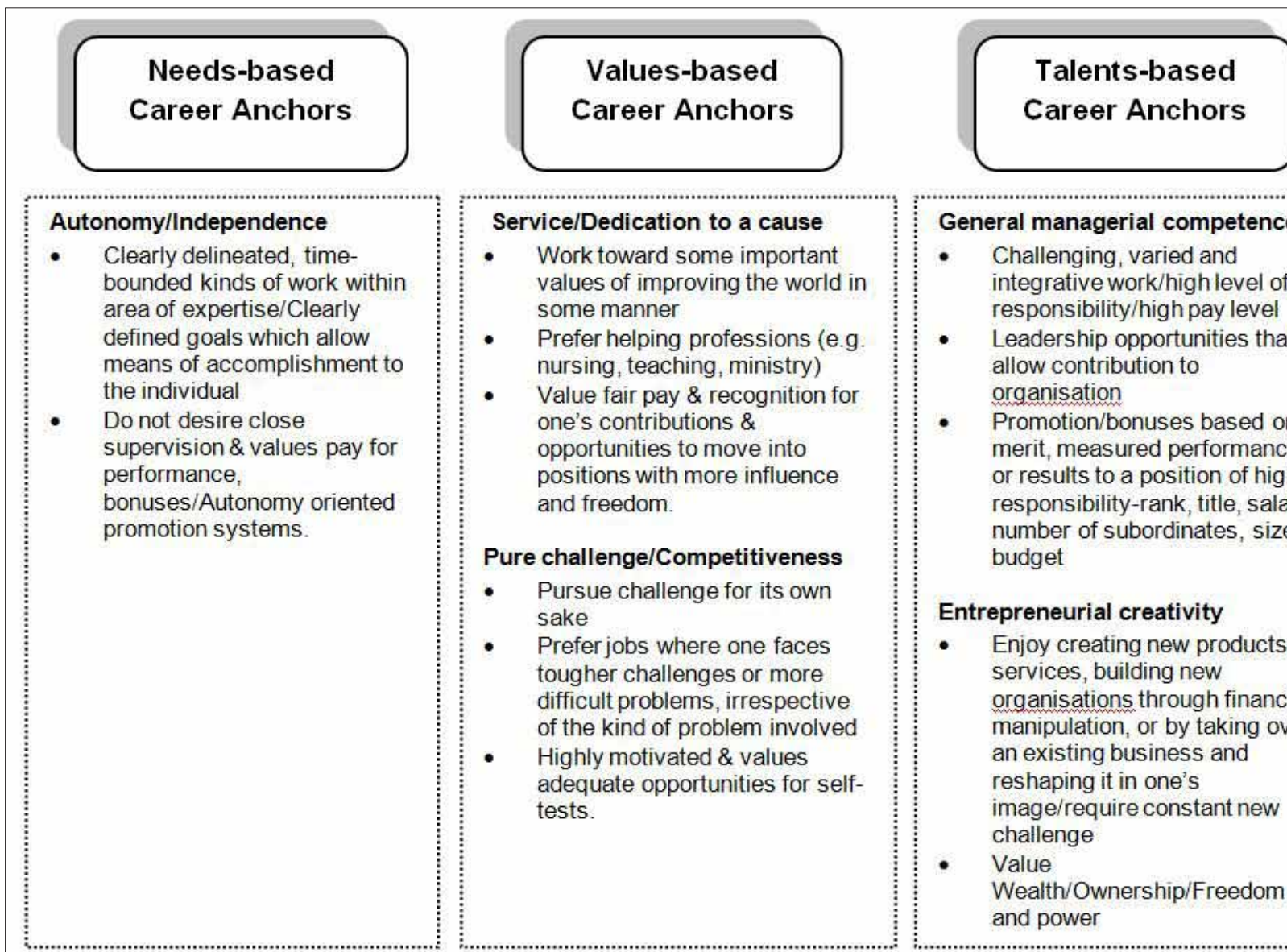

General managerial competence

- Challenging, varied and integrative work/high level of responsibility/high pay level

- $\quad$ Leadership opportunities that allow contribution to organisation

- Promotion/bonuses based on merit, measured performance, or results to a position of higher responsibility-rank, title, salary, number of subordinates, size of budget

\section{Entrepreneurial creativity}

- Enjoy creating new products or services, building new organisations through financial manipulation, or by taking over an existing business and reshaping it in one's image/require constant new challenge

- Value

Wealth/Ownership/Freedom and power 
2. Technical or functional competence is the motivation to develop one's technical or functional knowledge and expert skill.

3. General managerial competence, which can be described as the desire to attain a position that requires the application of interpersonal, political, analytical and financial skills associated with management.

4. Entrepreneurial or creativity, the need to create or build (rather than manage) something that is entirely one's own project.

5. Lifestyle, the need to integrate work, family and selfconcerns into a coherent lifestyle.

6. Pure challenge, the need to test one's abilities by singlemindedly focusing on winning out over or competing with extremely tough opponents and solving a variety of challenging problems.

7. Service or dedication to a cause, the need to align work activities with personal skills and values related to helping society and to improve the world in some fashion.

8. Security or stability, the need for job security associated with benefit packages and long-term employment in an organisation and stability in a geographical area.

Feldman and Bolino $(1996,2000)$ reconceptualised Schein's eight career anchors, dividing them into three distinct groupings along with their inherent motivations. These motivations are described as being either talent-based, need-based or valuebased anchors. The work of these authors provided a useful framework for the present study.

The talent-based anchors consist of:

- managerial competence (willingness to solve complex, whole-of-organization problems and undertake subsequent decision-making)

- technical or functional competence (the achievement of expert status among peers)

- entrepreneurial creativity (the opportunity for creativity and identification of new businesses, products or services).

The need-based anchors consist of:

- security and stability (long-term employment for health benefits and retirement options)

- autonomy and independence (personal freedom in job content and settings)

- lifestyle motivations (balancing one's personal and the family's welfare with work commitments).

The value-based anchors consist of:

- pure challenge (testing personal endurance through risky projects or physically challenging work)

- service and dedication to a cause (working for the greater good of organisations or communities).

Research conducted by Coetzee and Schreuder (2009a) on the structural equivalence of Schein's (1978) original eightfactor career orientations or anchors model for South African populations, culminated in a five-factor career orientations model for the South African organisational context and consists of the following career anchors or orientations:

1. autonomy or independence

2. general managerial competence

3. entrepreneurial or creativity

4. pure challenge (which Coetzee and Schreuder label pure challenge or competitiveness)

5. service or dedication to a cause.

The suggested five-factor career orientations model depicted in Figure 1 is of relevance to the present study owing to its relevance to the South African organisational context.

\section{Subjective work experiences}

In the context of this research, subjective work experiences consist of employees' self-evaluations, perceptions, attitudes, feelings and psychological experiences which characterise their life satisfaction, job and career satisfaction, personal happiness and the meaning they attach to work (Coetzee \& Bergh, 2009). Research has shown that both factors intrinsic to employees and extrinsic work-related determinants contribute to employees' subjective experiences of their lives, jobs or careers, their general state of happiness and perceptions of work as a meaningful activity in their lives. Personal intrinsic factors generally include individual difference factors or personal dispositions and traits such conscientiousness (Ashton, 2007; De Fruyt \& Salgado, 2003; Flett, 2007; Maltby, Day \& Macaskill, 2007), as well as positive emotionality or affectivity, for example, happiness, hope and optimism (Peterson \& Seligman, 2003; Snyder \& Lopez, 2002) and personal biographical factors such as age, gender and marital status (Arnold \& Cohen, 2008). Work-related factors generally relate to task and skill variety, autonomy, meaningfulness and whether the nature of jobs allows employees to feel satisfied in their jobs and provide opportunities to grow.

Satisfaction with life is defined as a global evaluation by individuals of their lives (Diener, Gohm, Suh \& Oishi, 2000). Life satisfaction refers to a person's subjective perception that all aspects of life are more or less in balance and according to personal expectations, which contribute to the level of personal happiness a person may experience. Happiness is therefore regarded as an important component of general life satisfaction and subjective well-being (Perrone, Webb, Wright, Jackson \& Ksiazak, 2006; Seligman, 2002; Snyder \& Lopez, 2002).

Happiness refers to an emotional, cognitive and even physiological sense that life is good with as little pain as possible (Seligman, 2002; Snyder \& Lopez, 2002). Happiness is generally related to aspects such as the enjoyment of a good or pleasurable life as well as aspects beyond pleasure. These may include good health and social interactions, religion, love and marriage, work and internal experiences (e.g. internal motivation, flow and meaningfulness in work and life) (Diener \& Seligman, 2002; Diener \& Seligman, 2004; Lucas, Clark, Georgellis, \& Diener, 2004). Boehm and Lyubomirsky (2008) posit that happiness should be viewed as one of the major sources of positive outcomes in the workplace. Happiness at work is about mindfully making the best use of the resources individuals have to overcome the challenges they face. Actively relishing the highs and managing the lows help individuals maximise their performance and achieve their potential. Others are also energised and affected by people's sense of happiness (Pryce Jones, 2010).

Dawis (1984) regards job satisfaction as cognition with affective components that results from certain perceptions about one's work and which has behavioural consequences such as tenure, longevity, physical health, mental health and productivity. As a cognition, job satisfaction is linked to other personal cognitions and work-related outcomes such as self-esteem, job involvement, work alienation, organisational commitment, morale, career and life satisfaction (Fritzsche \& Parrish, 2005; Herr, Cramer \& Niles, 2004). Whereas job satisfaction usually centres on one's immediate emotional reactions to one's current job, career satisfaction is a broader reflection of individuals' satisfaction with both past and future work history taken as a whole. As a holistic concept, career satisfaction is defined by people's reactions to their unfolding career and job experiences and their personal points of view, which may include pay and social position and issues such as well-being and emotions (Kidd, 2008). Career satisfaction is also regarded as a core measure of individuals' experiences of intrinsic career success, life satisfaction and job satisfaction (Judge \& KammeyerMueller, 2007)

Work is regarded as a central and fundamental activity in people's lives and has been linked to job or career satisfaction (Harpaz \& Fu, 2002; Whitehead \& Kotze, 2003). In addition to its obvious economic functions, work has a powerful potential 
to fulfill other important roles and needs of the individual such as personal growth and skills development, self-esteem, psychological fulfillment, identity, social interaction and sustaining a standard of living and status (Harpaz \& Fu, 2002). People also strive towards various goals and values through work which result in work being regarded as a valuable activity that influences people's general life satisfaction and happiness. Barrick and Ryan (2003) refer to a large body of research indicating the positive influence of positive emotions, for example personal happiness and related aspects such as life satisfaction, on work performance and work attitudes. Research conducted by Whitehead and Kotze (2003) and Woodd (2000) indicated that people's main motivations for working were related to intrinsic values that give their lives meaning.

In view of the apparent paucity of research concerning the five-factor career orientations model suggested by Coetzee and Schreuder (2009a) and individuals' subjective work experiences as represented by their perceived life and job or career satisfaction, sense of happiness and perceptions of work as a valuable activity in the South African organisational context, the present study aims to empirically assess whether there is a causal relationship between these variables. On the basis of research (Arthur et al., 2005; Brown et al., 2003; Coertse \& Scheepers, 2004; Coetzee \& Bergh, 2009; Coetzee \& Schreuder, 2009b; Ebberwein, Krieskok, Ulven \& Prosser, 2004; Judge et al., 2005; Kim, 2005; Van Dam, 2004) that has revealed relationships between subjective or psychological career variables such as career orientations, personality attributes, emotional intelligence, career resiliency and career maturity and a number of career related variables such as career adaptability, job or career satisfaction, life satisfaction, goal attainment, career decision making and entrepreneurial activity, the following research hypothesis was formulated:

Hypothesis 1: Individuals' career orientations significantly influence their levels of life satisfaction, job or career satisfaction and happiness and their perception of work as a valuable activity.

\section{RESEARCH DESIGN}

\section{Research approach}

For the exploratory pilot study reported on in this article, a quantitative survey design was used to achieve the research objective.

\section{Research method \\ Participants}

The participants were a random sample of employed students registered across various fields of study at a higher distance education institution for a particular year. The descriptive statistics revealed that the total sample of 2997 constituted predominantly African participants (41\%) followed by White participants (31\%). Indians, Coloureds and other minority cultural groups speaking languages such as Portuguese, German, Polish, French and Chinese were under-represented $(5 \%)$. Overall, Black $(67 \%)$ and female $(58 \%)$ participants predominated in the sample. The sample was predominantly represented by participants in the early adulthood life stage (25-40 years) (82\%). The mean age of the participants was 32, which implies well-established internal career preferences and values (Schein, 1996).

The sample of participants had generally attained a relatively high educational level, with $84 \%$ having attained a Grade 12 qualification, diploma and undergraduate higher education qualification. Students with a post-graduate qualification represented only $3 \%$ of the sample. The majority of the participants was in full-time employment $(80 \%)$ and occupied relatively high-level positions at senior and middle management level (18\%) and middle- and first-level supervisory level (54\%) in the service industry $(81 \%)$.
The following economic sectors were represented, government $(35 \%)$; services $(15 \%)$; financial, insurance, real-estates and business $(18 \%)$; wholesale and retail $(7 \%)$; transport, storage and communication $(6 \%)$ and other sectors, such as agriculture mining; manufacturing; electricity or gas and construction $(19 \%)$. The predominant fields of expertise reported by the participants were as follows: finance field (including accounting, auditing, banking and economics) (21\%); education $(11 \%)$; human resource management $(9 \%)$; protective services (i.e. SAPS; security, military) $(9 \%)$; health care $(8 \%)$; marketing, media or communication (6\%); public administration $(6 \%)$ information technology (5\%); legal or law $(3 \%)$; retail or sales $(5 \%)$ and catering or hospitality ( $2 \%)$.

\section{Measuring instruments}

An adapted version of the Career Orientations Inventory (COI) developed by Schein in collaboration with DeLong (1982a, 1982b) and a 4-item global subjective work experiences scale (Bergh, 2009) were used to measure the variables of concern to this study.

Career Orientations Inventory (COI): The original COI (DeLong, 1982a, 1982b) is a self-rated measure containing 41 items. To avoid neutral answers, a 10-point Likert-type scale was used for subject responses to each of the 41 items. Based on Schein's $(1974,1978)$ eight career anchors model these items related to perceived importance of an agreement with statements. Total scores obtained for each of the eight categories of career anchors were added together and averaged to yield an individual score for each career anchor. The COI provides a pretested instrument with demonstrated high internal validity and reliability (Burke, 1983; Custodio, 2004; DeLong, 1982a, 1982b; Wood, Winston \& Polkosnik, 1985). Custodio (2004) reports Cronbach alpha reliability coefficients ranging from 0.78 to 0.84 , while Coetzee and Schreuder (2008) report Cronbach alpha coefficients ranging from 0.46 (lifestyle) to 0.85 (entrepreneurial creativity).

For the purpose of this research, only the items related to the five-factor model identified by Coetzee and Schreuder (2009a) were retained in the questionnaire. As shown in Table 1, the reliability of the five-factor career orientations model was determined by means of Cronbach's alpha coefficient which ranged from 0.71 to 0.86 .

Subjective Work Experiences Scale: A single 4-item subjective work experiences scale (Bergh, 2009) measuring global selfperceived life satisfaction, job or career satisfaction, happiness and participants' perception of their work as a valuable activity was used. The selection of the four items was based on aspects pointed out by researchers in the field of careers and organisational behaviour as being factors influencing employees' psychological experiences of career success and organisational commitment (Arthur et al., 2005; Judge et al., 2005; Perrone et al., 2006; Sempane, Rieger \& Roodt 2002; Whitehead \& Kotze, 2003). Researchers (Schimmack \& Oishi,

TABLE 1

Cronbach's alpha coefficients

\section{Cronbach's}

Alpha Coefficient

\section{COI variables}

General managerial competence (GenMan)

Autonomy or Independence (Autonomy)

Service or Dedication to a cause (Service)

0.82

Pure challenge or Competitiveness (Compete)

0.71

Entrepreneurial creativity (EntCreat)

0.78

0.77

0.86

\section{SWE items}

Generally I feel satisfied with my life (Life satisfaction)

0.45

I am satisfied in my job or career (Job or career satisfaction)

On average I am a happy person (Happiness)

0.55

Work is a valuable activity (Work valuable activity)

0.58

COl, Care Oient 
2005; Wanous, Reichers \& Hudy, 1997; Woods \& Hampson, 2005) have also advocated that the psychometric properties of single item measures such as the SWES generally compare well with multiple-item measurement scales. A 5-point Likert-type scale was used for subject responses to each of the four items. In terms of validity, inter-item correlations conducted on the four items ranged from 0.13 to $0.56(p \leq 0.01)$, indicating small to large practical effect size. As shown in Table 1, the reliability of the four items was determined by means of Cronbach's alpha coefficient which ranged from 0.45 to 0.71 .

Seeing as the purpose of the present study was not to make individual predictions based on the adapted version of the COI and the global SWE scale, but rather to investigate broad trends and certain relations between variables, the instruments were considered to be psychometrically acceptable.

\section{Research procedure}

Using the postal facilities of the institution, questionnaires were posted to a randomly selected number of 6000 students who were registered at the higher education institution for the particular year. Each questionnaire was accompanied by a covering letter inviting subjects to participate in the study and assuring them that their individual responses would remain confidential. Participants were asked to complete the questionnaires and return them by mail to the researchers using the return envelope supplied. In total, 2997 usable questionnaires were returned. The questionnaires were scored electronically.

\section{Statistical analysis}

As per the research aim and hypothesis, the intention was to conduct a causal investigation of the five-factor career orientations model suggested by Coetzee and Schreuder (2009a) by using structural equation analysis or modelling. Structural equation modeling (SEM) is a multivariate procedure that combines multiple regression and factor analysis in examining a researcher's hypotheses of causality within a system. SEM is divided into two parts, a measurement model and a structural model. The measurement model deals with the relationships between measured variables and latent variables, while the structural model deals with the relationships between latent variables only. The abilities of SEM to distinguish between indirect and direct relationships between variables and to analyse relationships between latent variables without random error differentiate SEM from other simpler, relational modeling processes such as multiple regression (Hoyle, 1995).

As a confirmatory approach, a model is postulated, based on theory and empirical evidence from previous research. In the context of this study, the first model therefore represented the five-factor career orientations model as proposed by Coetzee and Schreuder (2009a) as the measurement or input part of the model and to postulate relationships between the five latent variables measuring career orientations and the subjective work experience measure (Bergh, 2009) as representing four directly observed variables in the structural part of the model. The model was then tested in a single group analysis, using SEM goodness-of-fit tests to determine whether the pattern of variances and covariances in the data was consistent with the postulated theoretical model (Garson, 2008). The SEM process focuses on validating the measurement model by obtaining estimates of the parameters of the model and by assessing whether the model itself provides a good fit to the data (Garson, 2008).

To investigate lack-of-fit, each sub-scale or dimension is then evaluated individually. Firstly, the face validity of each item as a measure of the proposed dimension was evaluated in the context of this study. Secondly, the reliability of each dimension was evaluated and items that lowered the reliability of the dimension were then removed until none of the items within the dimension lowered the reliability. Subsequent to the reliability analysis, a second model, which is also the core focus of this study, was then tested. This model excluded the items that were indicated as performing poorly in the item-reliability analyses and also excluded the dimensions that did not perform well.

The model adequacy was evaluated by means of goodness-of-fit measures. Goodness-of-fit tests determine whether the model being tested should be accepted or rejected (Garson, 2008). The model chi-square was used as it is the most common goodnessof-fit test when comparing models (Strasheim, 2008). With the chi-square, the difference between the observed data and the hypothesised model is tested (Garson, 2008). A significant chi-square indicates lack of satisfactory model fit, while a nonsignificant chi-square indicates a good model fit. However, a limitation of the chi-square test is that the size of the sample has an impact on chi-square values. Garson (2008) suggests that if the sample is large (as in the case of this study), even small differences between the model and the data will result in a statistical significance. Hence with large samples the chisquare will almost certainly be significant (Hox \& Bechger, 1998). A variety of alternative fit indices have therefore been proposed by researchers (Garson, 2008; Hu \& Bentler, 1999). All goodness-of-fit measures are some function of the chi-square $(\mathrm{CMIN})$ and degrees of freedom $(d f)$. These alternative indices consider not only the fit of the model but also its simplicity. Even though the goodness-of-fit indices still depend on sample size and distribution, the dependency is much smaller than that of the routine chi-square test (Hox \& Bechger, 1998).

The Goodness-of-Fit Index (GFI) indicates the relative amount of the variances or covariances in the sample predicted by the estimates of the population. In addition, the Adjusted Goodness-of-Fit Index (AGFI) is a measure of the relative amount of variance accounted for by the model, corrected for the degrees of freedom in the model relative to the number of variables. GFI and AGFI range between 0 and 1 and when models fit well, these indices will be closer to 1.00. The NonNormed Fit Index (NNFI), or Tucker-Lewis Index (TLI) as it is termed in the statistical package AMOS 17.0 which was utilised in the present study is a relative measure of covariation explained by the model (Garson, 2008). With regard to the TLI fit index, it is generally accepted that a value of less than 0.90 indicates that the fit of the model can be improved (Hoyle, 1995), although a revised cut-off value close to 0.95 has been advised by Hu and Bentler (1999).

To overcome the problem of sample size, Brown and Cudeck (1993) suggest using the Root Mean Square Error of Approximation (RMSEA) and the $90 \%$ confidence interval of the RMSEA. The primary principle of the RMSEA is that it evaluates the extent to which the model fails to fit the data. The RMSEA estimates the overall amount of error, it is a function of the fitting function value relative to the degrees of freedom. The RMSEA point estimate should be 0.05 or less and the upper limit of the confidence interval should not exceed 0.08 (Raykov \& Marcoulides, 2000). Hu and Bentler (1999) suggested a value of 0.06 as being indicative of good fit between the hypothesised model and the observed data. Fabrigar, Wegener, MacCallum and Strahan (1999) elaborated on these cut-off points and noted that RMSEA values ranging from 0.08 to 0.10 indicate mediocre fit and those greater than 0.10 indicate poor fit. The statistical significance level for the interpretation of the findings was set at $p \leq 0.05$.

\section{RESULTS}

The causal model depicted in Figure 2 shows all possible path coefficients from the five latent career orientations variables measuring career orientations to the construct subjective work experiences (SWE) which is represented by the four directly observable variables:

- life satisfaction

- job or career satisfaction

- happiness

- work as valuable activity.

This model has 81 parameters and a good fit, with a chi-Square of $1651.004(244 d f) ; \mathrm{CMIN} / d f=6.766 ; p=0.000$; GFI $=0.956$, 
AGFI $=0.942 ; \mathrm{IFI}=0.943, \mathrm{TLI}=0.930, \mathrm{RMSEA}=0.044$ and the $90 \%$ confidence interval of the RMSEA ranging between 0.042 and 0.046 . It must be noted that although the highly significant chi-square measure for the model indicates a poor fit, given the large sample size, it would be incorrect to conclude a poor fit based on the significance of the chi-square index only (Garson, 2008; Hu \& Bentler, 1999). The alternative indices all indicate a good fit.

Apart from the fit measures, the significance of the estimated regression coefficients between the latent $\mathrm{COI}$ variables and the observed SWE variables in the structural part of the model (provided in Tables 2 and 3) were also considered.
Table 2 shows that with the exception of the coefficients between the career orientations variable entrepreneurial creativity and work as valuable activity $(p \leq 0.06)$, all the coefficients between the COI and SWE variables are significant at the 5\% level of significance. The path or regression coefficients between the five COI variables and the four SWE variables generally vary from 1 and above, with the exception of the coefficients between the COI variable autonomy or independence and all four of the SWE variables from 0.16 to 0.92 and the service or dedication to a cause COI variable and the SWE variables happiness $(0.91)$ and work as a valuable activity (0.42). The highest coefficients (and thus strongest relationships) are observed between the COI pure challenge or competitiveness variable and the

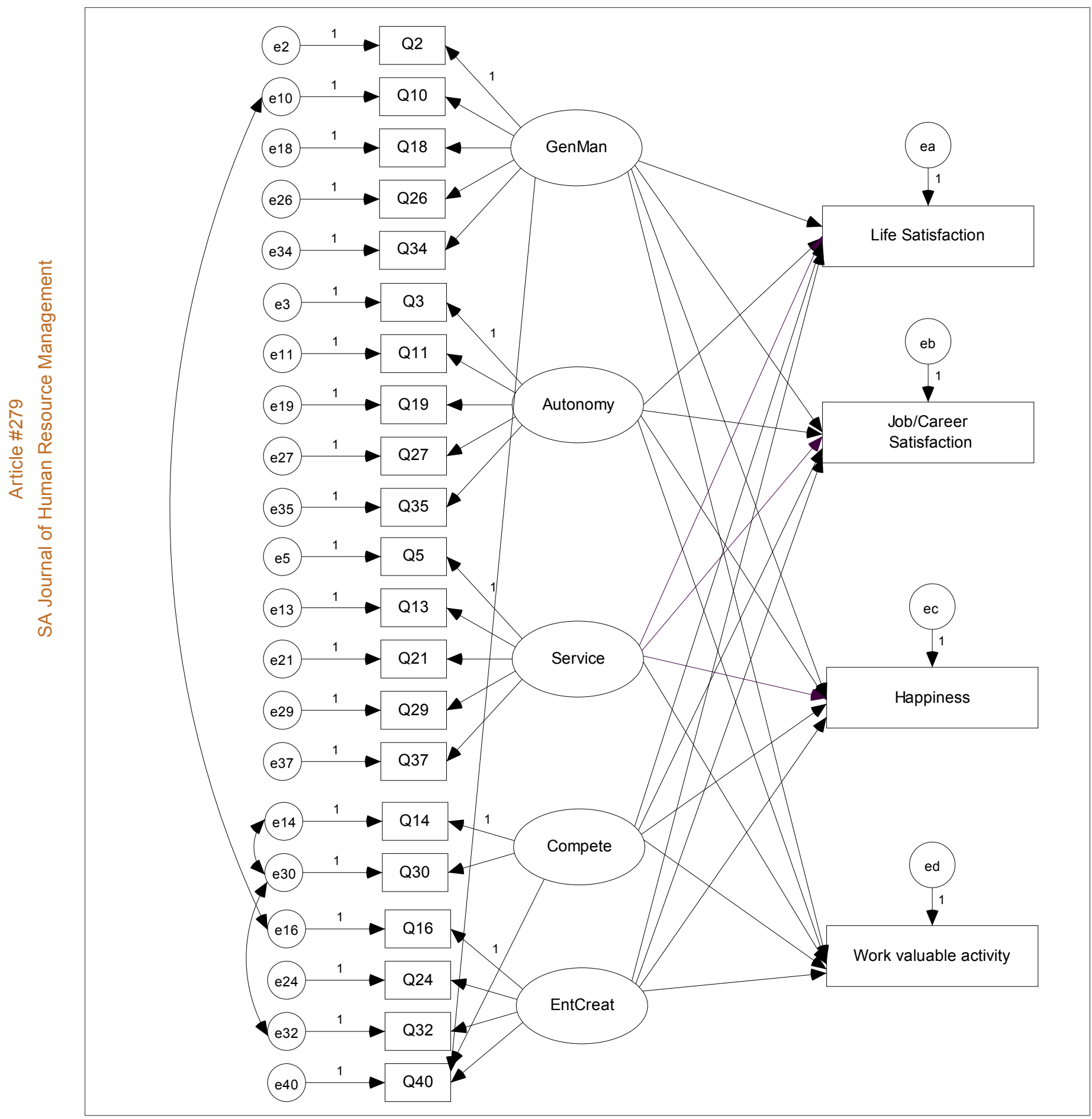

FIGURE 2

Causal model depicting the relationship between the five Career Orientations Inventory variables and four Subjective Work Experiences variables 
TABLE 2

Maximum likelihood estimated regression weights (Career Orientations Inventory five-factor model and Subjective Work Experiences four factor model)

\begin{tabular}{|c|c|c|c|c|c|c|c|}
\hline & & & Estimate & SE & CR & $p$ & Significance \\
\hline$\overline{\mathrm{Q} 40}$ & $\leftarrow$ & GenMan & 0.974 & 0.526 & 1.851 & 0.064 & None \\
\hline Q34 & $\leftarrow$ & GenMan & 1.347 & 0.046 & 29.107 & $<0.001$ & $* * *$ \\
\hline Q26 & $\leftarrow$ & GenMan & 1.078 & 0.036 & 29.573 & $<0.001$ & $* * *$ \\
\hline Q18 & $\leftarrow$ & GenMan & 1.255 & 0.038 & 33.176 & $<0.001$ & $* * *$ \\
\hline Q10 & $\leftarrow$ & GenMan & 1.379 & 0.042 & 33.193 & $<0.001$ & $* * *$ \\
\hline Q2 & $\leftarrow$ & GenMan & 1.000 & - & - & - & - \\
\hline Q35 & $\leftarrow$ & Autonomy & 0.790 & 0.040 & 19.642 & $<0.001$ & $* * *$ \\
\hline Q27 & $\leftarrow$ & Autonomy & 0.813 & 0.040 & 20.120 & $<0.001$ & $* * *$ \\
\hline Q19 & $\leftarrow$ & Autonomy & 1.040 & 0.042 & 24.857 & $<0.001$ & $* * *$ \\
\hline Q11 & $\leftarrow$ & Autonomy & 1.147 & 0.044 & 26.008 & $<0.001$ & $\star \star \star *$ \\
\hline Q3 & $\leftarrow$ & Autonomy & 1.000 & - & - & - & - \\
\hline Q37 & $\leftarrow$ & Service & 1.222 & 0.043 & 28.162 & $<0.001$ & $* * *$ \\
\hline Q29 & $\leftarrow$ & Service & 1.460 & 0.054 & 26.853 & $<0.001$ & $* * *$ \\
\hline Q21 & $\leftarrow$ & Service & 1.109 & 0.037 & 30.246 & $<0.001$ & $* \star *$ \\
\hline Q13 & $\leftarrow$ & Service & 1.014 & 0.033 & 30.951 & $<0.001$ & $* * *$ \\
\hline Q5 & $\leftarrow$ & Service & 1.000 & - & - & - & - \\
\hline Q40 & $\leftarrow$ & Compete & -1.699 & 0.616 & -2.760 & 0.006 & $* *$ \\
\hline Q30 & $\leftarrow$ & Compete & 1.127 & 0.036 & 31.297 & $<0.001$ & $* * *$ \\
\hline Q14 & $\leftarrow$ & Compete & 1.000 & - & - & - & - \\
\hline Q40 & $\leftarrow$ & EntCreat & 1.757 & 0.135 & 13.009 & $<0.001$ & $* \star \star$ \\
\hline Q32 & $\leftarrow$ & EntCreat & 0.924 & 0.024 & 38.321 & $<0.001$ & $* * *$ \\
\hline Q24 & $\leftarrow$ & EntCreat & 1.088 & 0.023 & 48.013 & $<0.001$ & 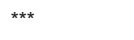 \\
\hline Q16 & $\leftarrow$ & EntCreat & 1.000 & - & - & - & - \\
\hline Life Satisfaction & $\leftarrow$ & GenMan & 12.576 & 5.815 & 2.163 & 0.031 & * \\
\hline Job or Career Satisfaction & $\leftarrow$ & GenMan & 10.090 & 4.646 & 2.172 & 0.030 & * \\
\hline Happiness & $\leftarrow$ & GenMan & 5.692 & 2.651 & 2.147 & 0.032 & * \\
\hline Work Valuable Activity & $\leftarrow$ & GenMan & 2.036 & 0.965 & 2.110 & 0.035 & * \\
\hline Life Satisfaction & $\leftarrow$ & Autonomy & 0.918 & 0.431 & 2.128 & 0.033 & * \\
\hline Job or Career Satisfaction & $\leftarrow$ & Autonomy & 0.694 & 0.345 & 2.012 & 0.044 & * \\
\hline Happiness & $\leftarrow$ & Autonomy & 0.424 & 0.197 & 2.158 & 0.031 & * \\
\hline Work Valuable Activity & $\leftarrow$ & Autonomy & 0.162 & 0.073 & 2.240 & 0.025 & * \\
\hline Life Satisfaction & $\leftarrow$ & Service & 1.796 & 0.761 & 2.361 & 0.018 & * \\
\hline Job or Career Satisfaction & $\leftarrow$ & Service & 1.398 & 0.608 & 2.297 & 0.022 & * \\
\hline Happiness & $\leftarrow$ & Service & 0.905 & 0.347 & 2.609 & 0.009 & ** \\
\hline Work Valuable Activity & $\leftarrow$ & Service & 0.422 & 0.128 & 3.293 & $<0.001$ & 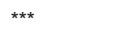 \\
\hline Life Satisfaction & $\leftarrow$ & Compete & -15.542 & 7.017 & -2.215 & 0.027 & * \\
\hline Job or Career Satisfaction & $\leftarrow$ & Compete & -12.411 & 5.607 & -2.214 & 0.027 & * \\
\hline Happiness & $\leftarrow$ & Compete & -7.090 & 3.199 & -2.217 & 0.027 & * \\
\hline Work Valuable Activity & $\leftarrow$ & Compete & -2.523 & 1.165 & -2.166 & 0.030 & * \\
\hline Life Satisfaction & $\leftarrow$ & EntCreat & 2.665 & 1.336 & 1.994 & 0.046 & * \\
\hline Job or Career Satisfaction & $\leftarrow$ & EntCreat & 2.088 & 1.068 & 1.956 & 0.050 & * \\
\hline Happiness & $\leftarrow$ & EntCreat & 1.233 & 0.609 & 2.023 & 0.043 & * \\
\hline Work Valuable Activity & $\leftarrow$ & EntCreat & 0.412 & 0.221 & 1.863 & 0.062 & None \\
\hline
\end{tabular}

$\mathrm{SE}$, standard error; $\mathrm{CR}$, critical ratio.

${ }^{*}$ Level of significance.

TABLE 3

Maximum likelihood estimated covariances (Career Orientations Inventory five-factor model and Subjective Work Experiences four factor model)

\begin{tabular}{|c|c|c|c|c|c|c|c|}
\hline & & & Estimate & SE & CR & $\bar{p}$ & Significance \\
\hline GenMan & $\leftrightarrow$ & Autonomy & 0.807 & 0.061 & 13.146 & $<0.001$ & *** \\
\hline GenMan & $\leftrightarrow$ & Service & 0.505 & 0.036 & 13.842 & $<0.001$ & $* * *$ \\
\hline GenMan & $\leftrightarrow$ & Compete & 2.100 & 0.103 & 20.437 & $<0.001$ & $* * *$ \\
\hline GenMan & $\leftrightarrow$ & EntCreat & 1.793 & 0.087 & 20.544 & $<0.001$ & $* * *$ \\
\hline Autonomy & $\leftrightarrow$ & Service & 0.199 & 0.037 & 5.341 & $<0.001$ & $* * *$ \\
\hline Autonomy & $\leftrightarrow$ & Compete & 1.085 & 0.083 & 13.081 & $<0.001$ & $* * *$ \\
\hline Autonomy & $\leftrightarrow$ & EntCreat & 1.513 & 0.092 & 16.499 & $<0.001$ & $* * *$ \\
\hline Service & $\leftrightarrow$ & Compete & 0.630 & 0.050 & 12.525 & $<0.001$ & $* * *$ \\
\hline Service & $\leftrightarrow$ & EntCreat & 0.568 & 0.049 & 11.631 & $<0.001$ & $* * *$ \\
\hline Compete & $\leftrightarrow$ & EntCreat & 2.359 & 0.123 & 19.171 & $<0.001$ & *** \\
\hline e30 & $\leftrightarrow$ & e14 & 2.913 & 0.134 & 21.777 & $<0.001$ & $* * *$ \\
\hline e10 & $\leftrightarrow$ & e16 & 0.452 & 0.062 & 7.324 & $<0.001$ & $* * *$ \\
\hline e30 & $\leftrightarrow$ & e32 & 0.977 & 0.095 & 10.304 & $<0.001$ & *** \\
\hline
\end{tabular}

SE, standard error; CR, critical ratio.

* Level of significance. 
SWE life satisfaction (-15.54) and job or career satisfaction (-12.41) variables, the COI general managerial competence and life satisfaction variables (12.58) and general managerial competence and job or career satisfaction variables (10.09). An interesting observation is that a negative relationship is indicated between the COI pure challenge or competitiveness variable and the four SWE variables, suggesting that the higher the score on the pure challenge or competitiveness career orientation, the lower the score on life satisfaction, job or career satisfaction, happiness and work as a valuable activity.

The path coefficients between the COI variables shown in Table 3 suggest especially strong relationships between the general managerial competence and pure challenge or competitiveness (2.10), pure challenge or competitiveness and entrepreneurial creativity (2.36), general managerial competence and entrepreneurial creativity (1.79) and autonomy or independence and entrepreneurial creativity (1.51) variables, suggesting some overlap between them

However, due to the large standard errors observed for the path coefficients between the COI and SWE variables, it was decided to model the four SWE items as a single latent variable, labeled as SWE. Modification indices indicated a path to be added from 'work is a valuable activity' to 'happiness' and an additional path from the COI autonomy or independence variable to Q18 of the general managerial competence variable ('to rise to a high position in general management') which improved the model fit substantially. The regression coefficients in the simplified model were highly significant and the model fitted the data very well. The chi-square $=2.624(d f=1) ; \mathrm{CMIN} / \mathrm{DF}$ ratio $=2.624 ; p=0.105$ and GFI $=1.000$, AGFI $=0.996 ; \mathrm{IFI}=0.999$ $\mathrm{TLI}=0.995, \mathrm{RMSEA}=0.023$ and the $90 \%$ confidence interval of RMSEA 0.000 to 0.060 . Seeing as the results suggested that the dependent variable could be considered as a single latent variable labeled SWE, it was then incorporated as a single latent variable in the causal model depicted in Figure 3.

The simplified model depicted in Figure 3 provides a more parsimonious view of the relationship between the COI variables and the SWE construct. The model fitted the data very well, with the chi-square value $=1586.991$ and $d f=253$; CMIN $/$ $\mathrm{DF}=6.273 ; p=0.000$. The GFI $=0.958$, AGFI $=0.946 ; \mathrm{IFI}=0.946$ and TLI $=0.936$. The RMSEA $=0.042$ with the $90 \%$ confidence interval of RMSEA between 0.040 and 0.044 . Table 4 shows that significant relationships are observed between the SWE construct and the COI general managerial competence and pure challenge or competitiveness variables $(p \leq 0.05)$ only. Similarly, Table 5 shows a strong relationship between these two COI variables (2.07), including entrepreneurial creativity (1.81 and 2.45 respectively, suggesting some overlap between these constructs. The negative relationship observed between the SWE construct and the COI pure challenge or competitiveness variable suggests that the higher the career orientation towards pure challenge or competitiveness, the lower or more negative the subjective work experience. In terms of the SWE construct variables, Table 4 shows that the service or dedication to a cause career orientation relates significantly and positively with the SWE variable work as a valuable activity $(0.112 ; p \leq 0.001)$ and happiness correlates positively with work as a valuable activity $(0.14 ; p \leq 0.001)$.

\section{DISCUSSION}

The main objective of this study was to determine the relationship between participants' career orientations and their subjective work experiences. Overall, the structural equation modeling analyses suggested a significant causal relationship between these variables. The research hypothesis is therefore accepted. In interpreting the results, the following sociodemographic characteristics of the sample were kept in mind the participants were predominantly from the service industry and held mostly managerial and supervisory level positions. Furthermore, the sample represented predominantly Black and female participants in full time employment in the entry and establishment life or career stages (25-40 years, mean age 32$)$, most of whom were enrolled for undergraduate level studies at the higher education institution.

The strong relationship observed between the SWE construct and the general managerial competence and pure challenge or competitiveness career orientations on the one hand and the strong relationship observed between these two career orientations on the other hand, suggest that participants who value being in charge of an entire organisation, rising to a high managerial position and being able to supervise, influence, lead and control people at all levels also value being constantly challenged by a competitive situation and solving tough problems. This in turn suggests that participants' talent-driven career motives are strongly associated with their values-based career motives. Both career orientations seem to be strongly associated with a need to manage others in positions of higher seniority and responsibility. These findings are in line with an exploratory factor analysis conducted by Coetzee and Schreuder (2009a) which demonstrates that these two constructs overlap in terms of career motives that concern competition and winning, being constantly challenged by a competitive situation and solving tough problems that involve the supervision of others at higher levels of responsibility and authority.

Considering that the participants were predominantly employed in the service industry, the positive relationship observed between the pure challenge, autonomy and the service or dedication to a cause career orientations (which is also positively related to work as a valuable activity), further suggests that the participants value challenging opportunities to serve and help others and working toward some important values of improving the world in some manner. Coetzee, Bergh and Schreuder (2010) found in this regard that having a strong sense of career purpose or viewing one's career as a calling to serve (and not merely as a job or career) is a strong positive driver of people's perception of work being a valuable activity. In agreement with the foregoing, Blustein (2006) posits that working involves effort, activity and energy in given tasks that contribute to the overall social and economic welfare of a culture. The participants also seem to value fair pay and recognition for their contributions and prefer opportunities to move into positions with more influence and freedom to deal with tougher or more challenging problems concerning society at large.

The findings suggest that the career motives and values underlying the participants' career orientations significantly influence their subjective work experiences and especially their sense of life satisfaction and job or career satisfaction. It appears from the findings that participants who are motivated by the talent-based career motives and values which underlie the managerial competence career orientation have a positive experience or perception of their working lives. In this regard, Coetzee et al. (2010) found happiness to be positively predicted by a managerial career preference. On the other hand, those participants who are motivated by the values-based career orientation, pure challenge or competitiveness appear to perceive their subjective work experiences significantly more negative, with a significant lower sense of life and job or career satisfaction and happiness and a significantly negative perception of the working lives. Some of the major factors that have been reported to lead to job or career dissatisfaction include feeling bored and needing more stimulating and challenging work, having no opportunity to express one's creative ideas and/or talents and feeling underutilized and stuck with no clear future career path (Coetzee et al., 2010).

The results also suggest a strong relationship between the general managerial competence, pure challenge or competitiveness and entrepreneurial creativity career orientations. Research by Goffee and Sease (1992) indicates that people are encountering fewer opportunities for promotion in the contemporary workplace due to increased competitive pressures and corporate downsizing. Instead, individuals who 
have a strong managerial career anchor are often expected to behave as 'entrepreneurs' and to be flexible and responsive to changing work requirements. Coetzee et al. (2010) found entrepreneurial career motives to be a negative predictor of job or career satisfaction. They further note that people who are behaviourally adaptable have significantly more negative perceptions of their working lives.

Coetzee and Schreuder (2009b) further note that both the general management and entrepreneurial creativity career orientations show a negative association with the ability to adapt to changing situations and the ability to deal with setbacks and failures. This may be due to a high need for achievement, status, personal power and a sense of being in control, which are often linked to these two career orientations (Lee \& Wong,
2004). The negative relationship observed between the pure challenge or competitiveness and the participants' subjective work experiences constructs may be due to the constant need for a variety of new and challenging assignments, including opportunities for higher levels of authority and responsibility in a service orientated environment where they can make a difference.

\section{CONCLUSIONS, LIMITATIONS AND RECOMMENDATIONS}

Similar to findings reported by Coetzee and Schreuder (2009a, 2009b), the results of the present study suggest that the career orientations of the participants relate to different aspects of the

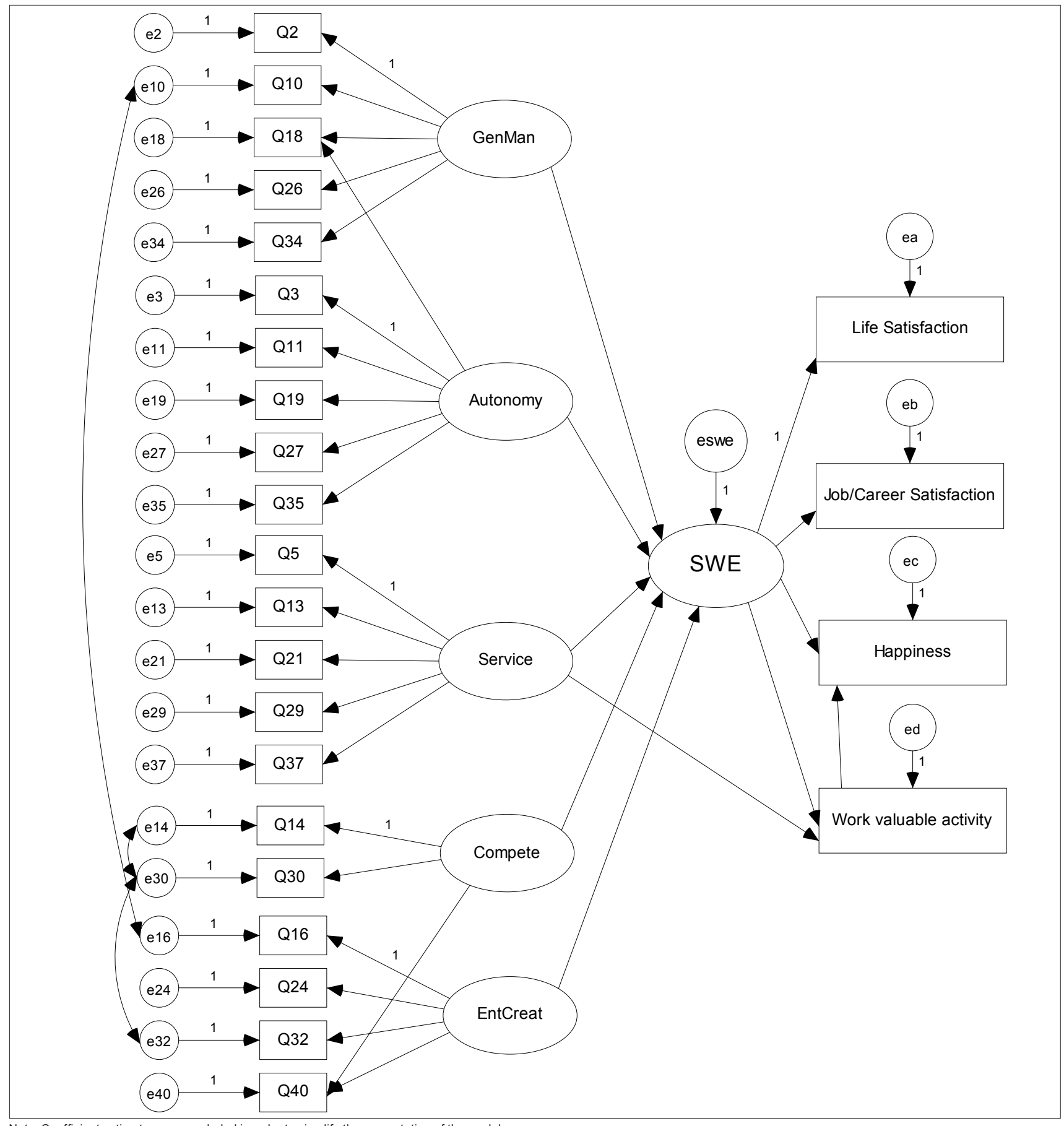

Note: Coefficient estimates were excluded in order to simplify the presentation of the mode

FIGURE 3

Causal model depicting the relationship between the five Career Orientations Inventory variables and the single Subjective Work Experiences construct 
TABLE 4

Maximum likelihood estimated regression weights (Career Orientations Inventory five-factor model and single Subjective Work Experiences construct)

\begin{tabular}{|c|c|c|c|c|c|c|c|}
\hline & & & Estimate & SE & CR & $p$ & Significance \\
\hline SWE & $\leftarrow$ & GenMan & 0.207 & 0.100 & 2.065 & 0.039 & * \\
\hline SWE & $\leftarrow$ & Autonomy & 0.011 & 0.019 & 0.582 & 0.560 & None \\
\hline SWE & $\leftarrow$ & Service & 0.041 & 0.030 & 1.386 & 0.166 & None \\
\hline SWE & $\leftarrow$ & Compete & -0.291 & 0.118 & -2.473 & 0.013 & * \\
\hline SWE & $\leftarrow$ & EntCreat & 0.026 & 0.026 & 1.012 & 0.311 & None \\
\hline Q2 & $\leftarrow$ & GenMan & 1.000 & - & - & - & - \\
\hline Q10 & $\leftarrow$ & GenMan & 1.391 & 0.042 & 32.912 & $<0.001$ & $* \star *$ \\
\hline Q18 & $\leftarrow$ & GenMan & 1.400 & 0.044 & 31.664 & $<0.001$ & $* * *$ \\
\hline Q26 & $\leftarrow$ & GenMan & 1.089 & 0.037 & 29.365 & $<0.001$ & $* \star *$ \\
\hline Q34 & $\leftarrow$ & GenMan & 1.371 & 0.047 & 29.098 & $<0.001$ & $* * *$ \\
\hline Q3 & $\leftarrow$ & Autonomy & 1.000 & - & - & - & \\
\hline Q18 & $\leftarrow$ & Autonomy & -0.243 & 0.029 & -8.290 & $<0.001$ & $* \star *$ \\
\hline Q35 & $\leftarrow$ & Autonomy & 0.787 & 0.040 & 19.635 & $<0.001$ & $* * *$ \\
\hline Q27 & $\leftarrow$ & Autonomy & 0.823 & 0.040 & 20.363 & $<0.001$ & $* * *$ \\
\hline Q19 & $\leftarrow$ & Autonomy & 1.032 & 0.042 & 24.830 & $<0.001$ & $\star * \star *$ \\
\hline Q11 & $\leftarrow$ & Autonomy & 1.146 & 0.044 & 26.114 & $<0.001$ & *** \\
\hline Q5 & $\leftarrow$ & Service & 1.000 & - & - & - & - \\
\hline Q13 & $\leftarrow$ & Service & 1.015 & 0.033 & 30.828 & $<0.001$ & $* \star *$ \\
\hline Q21 & $\leftarrow$ & Service & 1.112 & 0.037 & 30.162 & $<0.001$ & $* \star *$ \\
\hline Q29 & $\leftarrow$ & Service & 1.465 & 0.055 & 26.809 & $<0.001$ & $* * *$ \\
\hline Q37 & $\leftarrow$ & Service & 1.228 & 0.044 & 28.155 & $<0.001$ & $* * *$ \\
\hline Q14 & $\leftarrow$ & Compete & 1.000 & - & - & - & - \\
\hline Q30 & $\leftarrow$ & Compete & 1.117 & 0.035 & 31.527 & $<0.001$ & $* * *$ \\
\hline Q40 & $\leftarrow$ & Compete & -0.569 & 0.057 & -9.899 & $<0.001$ & *** \\
\hline Q16 & $\leftarrow$ & EntCreat & 1.000 & - & - & - & - \\
\hline Q24 & $\leftarrow$ & EntCreat & 1.083 & 0.023 & 48.028 & $<0.001$ & *** \\
\hline Q32 & $\leftarrow$ & EntCreat & 0.921 & 0.024 & 38.378 & $<0.001$ & $* * *$ \\
\hline Q40 & $\leftarrow$ & EntCreat & 1.549 & 0.048 & 32.581 & $<0.001$ & $* \star *$ \\
\hline Life Satisfaction & $\leftarrow$ & SWE & 1.000 & - & - & - & - \\
\hline Job or Career Satisfaction & $\leftarrow$ & SWE & 0.761 & 0.034 & 22.262 & $<0.001$ & $* \star *$ \\
\hline Happiness & $\leftarrow$ & SWE & 0.407 & 0.020 & 20.356 & $<0.001$ & $* * *$ \\
\hline Work Valuable Activity & $\leftarrow$ & SWE & 0.139 & 0.016 & 8.877 & $<0.001$ & *** \\
\hline Happiness & $\leftarrow$ & Work Valuable Activity & 0.139 & 0.017 & 8.165 & $<0.001$ & $* * *$ \\
\hline Work Valuable Activity & $\leftarrow$ & Service & 0.112 & 0.015 & 7.356 & $<0.001$ & $\star \star \star *$ \\
\hline
\end{tabular}

$\mathrm{SE}$, standard error; $\mathrm{CR}$, critical ratio.

* Level of significance.

TABLE 5

Maximum likelihood estimated covariances (Career Orientations Inventory five-factor model and single Subjective Work Experiences construct)

\begin{tabular}{|c|c|c|c|c|c|c|c|}
\hline & & & Estimate & SE & CR & $p$ & Significance \\
\hline GenMan & $\leftrightarrow$ & Autonomy & 0.909 & 0.064 & 14.118 & $<0.001$ & *** \\
\hline GenMan & $\leftrightarrow$ & Service & 0.498 & 0.036 & 13.861 & $<0.001$ & *** \\
\hline GenMan & $\leftrightarrow$ & Compete & 2.074 & 0.102 & 20.436 & $<0.001$ & $* * *$ \\
\hline GenMan & $\leftrightarrow$ & EntCreat & 1.807 & 0.087 & 20.725 & $<0.001$ & $* * *$ \\
\hline Autonomy & $\leftrightarrow$ & Service & 0.196 & 0.037 & 5.266 & $<0.001$ & *** \\
\hline Autonomy & $\leftrightarrow$ & Compete & 1.141 & 0.091 & 12.523 & $<0.001$ & $* * *$ \\
\hline Autonomy & $\leftrightarrow$ & EntCreat & 1.502 & 0.090 & 16.607 & $<0.001$ & $* \star *$ \\
\hline Service & $\leftrightarrow$ & Compete & 0.621 & 0.053 & 11.814 & $<0.001$ & $* \star \star$ \\
\hline Service & $\leftrightarrow$ & EntCreat & 0.532 & 0.048 & 11.195 & $<0.001$ & $* \star \star$ \\
\hline Compete & $\leftrightarrow$ & EntCreat & 2.450 & 0.127 & 19.307 & $<0.001$ & $* * *$ \\
\hline e10 & $\leftrightarrow$ & e16 & 0.464 & 0.062 & 7.535 & $<0.001$ & *** \\
\hline e30 & $\leftrightarrow$ & e32 & 0.932 & 0.096 & 9.681 & $<0.001$ & $* * *$ \\
\hline e30 & $\leftrightarrow$ & e14 & 2.406 & 0.210 & 11.437 & $<0.001$ & $* * *$ \\
\hline
\end{tabular}

$\mathrm{SE}$, standard error; $\mathrm{CR}$, critical ratio.

* Level of significance.

master career motives that underlie the general management, pure challenge and entrepreneurial or creativity career orientations which significantly influence their subjective work experiences and in particular their life and job or career satisfaction. This finding is contrary to Schein's (1978) argument that people tend to have one dominant career anchor and is more in keeping with Feldman and Bolino's (1996) observation that one to three career anchors (a combination of the talentsbased, values-based and needs-based career orientations) tend to cluster together to form an individual's career and work preferences.
The research confirms the need to assess the inner career orientations of employees as these provide valuable information regarding the motives and values driving individuals' career decision making and significantly influence their life and job or career satisfaction, sense of happiness and perceptions of work as a valuable activity. Individuals' master career motives and values form an integral part of their career consciousness. The career consciousness includes people's conscious, career-related cognitions (i.e. perceptions, awareness and self-evaluations) of their career preferences or orientations, values, skills, attitudes and behaviours that they understand and regard as being 
helpful in realising their goals and achieving career success (Coetzee, 2007). Because research (Coetzee et al., 2010; Coetzee \& Schreuder, 2008, 2009a, 2009b; Kanye \& Crous, 2007) has shown that employees' inner career orientations are related to their life satisfaction, job or career satisfaction, organisational commitment, performance and motivation, it is suggested that both quantitative and qualitative measures be employed to gain deeper insight into the broader career consciousness of the individual.

Given the paucity of empirical work on the causal relationship between the career orientations and subjective work experiences constructs relevant to this research, it would seem sensible not to over-interpret the present findings with reference to practical implications without further corroborative research. Nevertheless, two preliminary implications may be suggested. Firstly, as the findings illustrate that people's career orientations may potentially influence their life and job or career satisfaction, happiness and perceptions of work as a valuable activity, it is suggested that organisations and managers consider the importance of and need for more effective career matching which can be accomplished by offering multiple rewards and career paths that address the diverse career interests and needs of a multi-cultural workforce.

Favourable organisational conditions and career development support practices that foster proactive and effective career development and management may elicit higher levels of subjective and objective experiences of career success, possibly leading to other important outcomes such as job or career satisfaction, organisational commitment, talent retention, employee engagement and job performance. In this regard, retaining talent statistics (Hughes \& Half, 2009) indicate that compensation and benefits are often less of a reason why people leave and that the primary reasons employees stay at companies and are engaged include:

- the manager understands what motivates them

- they feel engaged in challenging and meaningful work

- they have career advancement opportunities

- they perceive their manager as being visible, honest and consistent

- the company shows an interest in their employees.

Employees who feel that their manager does not respect their psychological needs are three times more likely to leave the employer than those who feel respected.

Secondly, although the findings highlight the need for further research to explore the relationship between working adults' inner career orientations and their subjective work experiences, the practical value of the findings lies in the richness of new knowledge gained regarding the identified associations between participants' career orientations, life and job or career satisfaction, sense of happiness and perceptions of work as a valuable activity. Considering the competitive global and South African employment equity context, which has resulted in greater attention being paid to the retention of Black managerial talent in particular, the findings add valuable new knowledge that may be used to guide organisational career development support practices relating to the attraction, engagement, development and retention of managerial potential. Research by Kuijpers and Scheerens (2006) indicates that career support practices affect the career development ability, behaviour and motivation of employees. In light of the results of the present study, practices that satisfy the need for autonomy, challenging work, creativity and advancement can be satisfied, for example, by putting the manager in charge of a new project that has to be driven from the conceptual phase to the completion phase (Arnolds \& Boshoff, 2001). Creating a supporting environment in which diversely skilled employees on various levels interact, communicate, challenge, assist, trust and commit themselves to the search for new ideas in solving tough problems may help to reduce the feelings of dissatisfaction experienced by participants who value the pure challenge or competitiveness career orientation. Coetzee and Bergh (2009) also note that the education, guidance and coaching for self-empowering career behaviours and career meta-skills that clearly underpin individuals' inner career orientations may lead to higher levels of life and job or career satisfaction.

It is important to note that although the findings of this study apply predominantly to working adults in the entry and establishment phases of their lives, organisations and practitioners need to realise that adults across all life or career stages must continue to cope with trying to implement an evolving self-concept in their lifestyles, in their work, in their choices and in their career development planning. Most people struggle throughout their lives to find a satisfactory match between their career needs and preferences and those associated with their work life (Herr et al., 2004). Coetzee and Bergh (2009) suggest that establishing career development support practices that foster positive work experiences for all age, gender and race groups may enhance experiences of intrinsic career success and promote their life and job or career satisfaction and a general sense of well-being.

Seeing as the present study has been limited to participants employed predominantly in the South African service industry, the findings cannot be generalised to other occupational contexts. In addition, SEM cannot test directionality in relationships. The empirical causal models presented in this study represent only the researchers' hypothesis of causality within a system which limits the structural equation models' ability to recreate the sample covariance and variance patterns that have been observed in nature (Garson, 2008). These findings therefore need to be replicated with broader samples across various occupational groups and economic sectors before final conclusions can be drawn about the relationship between individuals' career orientations and subjective work experiences.

\section{REFERENCES}

Aamodt, M.G. (2010). Industrial/Organisational Psychology: An applied approach. (6 $6^{\text {th }}$ edn.). Belmont, CA: Wadsworth Cengage Learning.

Anastasiadou, S.D. (2007). Job commitment is highly influenced by job motives and job satisfaction: The case of Greek teachers in higher education. The International Journal of Knowledge, Culture and Change Management, 7 (7), 69-79.

Arnold, J., \& Cohen, L. (2008). The psychology of careers in industrial and organisational settings: A critical but appreciative analysis. In G.P. Hodgkinson \& J.K. Ford (Eds), International review of Industrial and Organisational Psychology Vol. 23 (pp. 1-43). London: John Wiley \& Sons.

Arnolds, C.A., \& Boshoff, C. (2001). The challenge of motivating top management: A need satisfaction perspective. Journal of Industrial Psychology, 27(1), 39-42.

Arthur, M.B., Khapova, S.N., \& Wilderom, C.P.M. (2005). Career success in a boundaryless career world. Journal of Organisational Behaviour, 26, 177-202.

Ashton, M.C. (2007). Individual differences and personality. Amsterdam: Academic Press.

Baruch, Y. (2004). Transforming careers: From linear to multidirectional career paths. Career Development International, 9(1), 58-73.

Barrick, M.R., \& Ryan A.M. (Eds). (2003). Personality and work: Reconsidering the role of personality in organisations. San Francisco, CA: Jossey-Bass.

Bergh, Z.C. (2009). Psychometric properties of the Subjective Work Experiences Scale. Unpublished research report, Department of Industrial and Organisational Psychology, University of South Africa, Pretoria, South Africa.

Blustein, D.L. (2006). The psychology of working: A new perspective for career development, counselling and public policy. Mahwah, NJ: Lawrence Erlbaum Associates. 
Boehm, J.K., \& Lyubomirsky, S. (2008). Does happiness promote career success? Journal of Career Assessment, 16(1), 101-116.

Brown, M.W., \& Cudeck, R. (1993). Alternative ways of assessing model fit. In: K.A. Bollen, J.S. Long (Eds.). Testing structural equation models (pp. 136-162). Newsbury Park, CA: Sage.

Brown, C., George-Curran, R., \& Smith, M.L. (2003). The role of emotional intelligence in the career commitment and decision-making process. Journal of Career Assessment, 11(4), 379-392.

Burke, R.J. (1983). Career orientations of Type A individuals. Psychological Reports, 53, 979-989.

Coertse, S., \& Scheepers, J.M. (2004). Some personality and cognitive correlates of career maturity. SA Journal of Industrial Psychology/SA Tydskrif vir Bedryfsielkunde, 30(2), 56-73.

Coetzee, M. (2007). Exploratory Factor Analyses of the Psychological Career Resources Inventory. Unpublished Research Report Department of Industrial and Organisational Psychology, University of South Africa, Pretoria, South Africa.

Coetzee, M., \& Bergh, Z. (2009). Psychological career resources and subjective work experiences of working adults: An exploratory study. SA Business Review, 13(2), 1-31.

Coetzee, M., Bergh, Z.C., \& Schreuder, A.M.G. (2010). Career orientations and psychological career resources as predictors of subjective work experiences. Unpublished research report, Department of Industrial and Organisational Psychology, University of South Africa, Pretoria, South Africa.

Coetzee, M., \& De Villiers, M.A. (2010). Sources of job stress, work engagement and career orientations of employees in a South African financial institution. SA Business Review,14 (1), 27-57.

Coetzee, M., \& Schreuder, A.M.G. (2008). A multi-cultural investigation of students' career anchors at a South African higher education institution. SA Journal of Labour Relations, $32(2), 1-21$.

Coetzee, M., \& Schreuder, A.M.G. (2009a). Using the Career Orientations Inventory (COI) for measuring career orientations in the South African organisational context. $S A$ Journal of Industrial Psychology/SA Tydskrif vir Bedryfsielkunde, 35(1), Article \#806, 13 pages. DOI: 10.4102/saip.v35i1.806.

Coetzee, M., \& Schreuder, A.M.G. (2009b). Psychological career resources as predictors of working adults' career anchors: An exploratory study. SA Journal of Industrial Psychology/SA Tydskrif vir Bedryfsielkunde, 35(1), Article \#833, 13 pages. DOI 10.4102/sajip.v35i1.833.

Custodio, L.P. (2004). Career anchors of Filipino academic executives. School of Commerce Research Paper Series: 00-13, College of Business and Accountancy, Virac.

Dawis, R.V. (1984). Job satisfaction: worker aspirations, attitudes, and behaviour. In N.C. Gysbers (Ed). Designing careers, counseling to enhance education, work and leisure. San Francisco: Jossey-Bass.

De Fruyt, F., \& Salgado, J.F. (2003). Personality and industrial, work and organisational applications. European Journal of Personality, 17,1 .

DeLong, T.J. (1982a). The career orientations of MBA Alumni: A multi-dimensional model. In R. Katz. (Ed.), Career Issues in human resource management (pp. 50-64). Upper Saddle River, NJ: Prentice-Hall

DeLong, T.J. (1982b). Reexamining the career anchor model. Personnel, 59(3), 60-61.

Derr, C.B. (1986). Managing the new careerist: The diverse career success orientations of today's workers. San Francisco: JosseyBass.

Derr, C.B., \& Briscoe, J.P. (2007). The catalyctic 1970s: Lessons for the 2000s. In H. Gunz \& M. Peiperl (Eds.), Handbook of career studies (pp. 528-541). London: Sage.

Diener, E., \& Seligman, M.E.P. (2002). Very happy people. Psychological Science, 13, 81-84.

Diener, E., \& Seligman, M.E.P. (2004). Beyond money: Toward an economy of well-being. Psychological Science in the Public Interest, 5(1), 1-31.

Diener, E., Gohm, C.L., Suh, E., \& Oishi, S. (2000). Similarity of the relations between marital staus and subjective wellbeing across cultures. Journal of Cross-cultural Psychology, 31, 419-436.
Driver, M.J. (1982). Career concepts: A new approach to career research. In R. Katz (Ed.), Career issues in human resource management (pp. 23-32). Englewood Cliffs, NJ: Prentice-Hall.

Ebberwein, C.A., Krieshok, T.S., Ulven, J.C., \& Prosser, E.C. (2004). Voices in transition: Lessons on career adaptability. The Career Development Quarterly, 52(4), 292-308.

Fabrigar, L.R., Wegener, D.T., MacCallum, R.C., \& Strahan, E.J. (1999). Evaluating the use of exploratory factor analysis in psychological research. Psychological Methods, 4(3), 272-299.

Feldman, D.C., \& Bolino, M.C. (1996). Careers within careers: Reconceptualising the nature of career anchors and their consequences. Human Resource Management Review, 6(2), $89-112$.

Feldman, D.C., \& Bolino, M.C. (2000). Career patterns of the selfemployed: Career motivations and career outcomes. Journal of Small Business Management, 38, 53-67.

Flett, G.L. 2007. Personality theory \& research. Ontario: Wiley \& Sons.

Fritzsche, B.A., \& Parrish, T.J. (2005). Theories and research on job satisfaction. In S.D. Brown and R.W. Lent (Eds.), Career development and counseling: Putting theory and research to work (pp. 180-202). Hoboken, NJ: John Wiley \& Sons.

Fugate, M., Kinicki, A.J., \& Ashforth, B.E. (2004). Employability: A psycho-social construct, its dimensions, and applications. Journal of Vocational Behaviour, 65, 14-38.

Garson, G.D. (2008). Structural Equation Modeling: Statnotes, PA765. Retrieved January 12, 2009, from http://faculty. chass.ncsu.edu/garson/PA765/structur.html

Goffee, R., \& Sease, R. (1992). Organisational change and the corporate career: The restructuring of managers' job aspirations. Human Relations, 45, 363-385.

Hall, D.T. (1976). Careers in organisations. Pacific Palisades, CA: Wiley.

Harpaz, I., \& Fu, X. (2002). The structure of the meaning of work: A relative stability amidst change. Human Relations, 55(6), 639-667.

Havran, H., Visser, D., \& Crous, F. (2003). The internal career orientations of permanent and contracting information technology staff. SA Journal of Industrial Psychology/SA Tydskrif vir Bedryfsielkunde, 29(3), 53-60.

Herr, E.L., Cramer, S.H., \& Niles, S.G. (2004). Career guidance and counseling through the lifespan. London: Prentice-Hall.

Hox, J.J., \& Bechger, T.M. (1998). An introduction to structural equation modeling. Family Science Review, 11, 354-373.

Hoyle, R.H. (Ed.). (1995). Structural equation modeling. Thousand Oaks, CA: SAGE

Hughes, L., \& Half, R. (2009). The war for talent. Retrieved May 14, 2009, from http://www.globalexpertbase.com/wp-8212.html

Hu, L.T., \& Bentler, P.M. (1999). Cut-off criteria for fit indices in covariance structure analysis: Conventional criteria versus new alternatives. Structural Equation Modeling, 6(1), 1-55.

Järlström, M. (2000). Personality preferences and career expectations of Finnish business students. Career Development International, 5(3), 144-154.

Jiang, J.J., \& Klein, G. (2000). Supervisor support and career anchor impact on the career satisfaction of the entry-level information systems professionals. Journal of Management Information Systems, 16(3), 219-240.

Jiang, J.J., Klein, G., \& Balloun, J.L. (2001). The joint impact of internal and external career anchors on entry-level IS career satisfaction. Information and Management, 39, 31-39.

Judge, T.A., Bono, J.E., Erez, A., \& Locke, E.A. (2005). Core self-evaluations and job and life satisfaction: The role of self-concordance and goal attainment. Journal of Applied Psychology, 90(92), 257-268.

Judge, T.A., \& Kammeyer-Mueller, J.D. (2007). Personality and career success. In H. Gunz \& M. Peiperl (Eds), Handbook of career studies (pp. 59-78). London: Sage.

Kanye, B., \& Crous, F. (2007). Graduate interns' experiences: A career success orientations approach. SA Journal of Industrial Psychology/SA Tydskrif vir Bedryfsielkunde, 33(3), 84-93.

Kidd, J.M. (2008). Exploring the components of career wellbeing and the emotions associated with significant career experiences. Journal of Career Development, 35, 166-186. 
Kim, N. (2005). Organisational interventions influencing employee career development preferred by different career success orientations. International Journal of Training and Development, 9(1), 47-61.

Kock, R., \& Burke, M. (2008). Managing talent in the South African Public Service. Retrieved May 14, 2009, from http://www. entrepreneur.com/tradejournals/article/192352088_2.html

Kokou, G., \& Ierodiakonou, C. (2007). Job satisfaction and employee commitment in the academic profession: A gender approach. International Journal of Knowledge, Culture and Change Management, 6(8), 101-123.

Kotze, K., \& Roodt, G. (2005). Factors that affect the retention of managerial and specialist staff: An exploratory study of an employee commitment model. SA Journal of Human Resource Management/SA Tydskrif vir Menslikehulpbronbestuur, 3(2), 48-55.

Kuijpers, M.A.C.T., \& Scheerens, J. (2006). Career competencies for the modern career. Journal of Career Development, 32(4), 303-319.

Lee, S.H., \& Wong, P.K. (2004). An exploratory study of technopreneurial intentions: A career anchor perspective. Journal of Business Venturing, 19(7), 7-28.

Lucas, R.E., Clark, A.E., Georgellis, Y., \& Diener, E. (2004). Unemployment alters the set point for life satisfaction. Psychological Science, 15 (1), 8-13.

Lumley, L. (2010). The relationship between career anchors, job satisfaction and organisational commitment. Unpublished master's dissertation, Department of Industrial and Organisational Psychology, University of South Africa, Pretoria, South Africa.

Maltby, J., Day, L., \& Macaskill, A. (2007). Introduction to personality, individual differences and intelligence. Harlow: Pearson/Prentice Hall.

Marchington, M., \& Wilkinson, A. (2008). Human resource management at work: People management and development. London: CIPD.

Martin, A., \& Roodt, G. (2008). Perceptions of organisational commitment, job satisfaction and turnover intentions in a post-merger South African tertiary institution. SA Journal of Industrial Psychology/SA Tydskrif vir Bedryfsielkunde, 34(1), 23-31.

Peterson, C., \& Seligman, M. E. P. (2003). Values in Action (VIA) classification of strengths. Retrieved August 20 2003, from http://www.psych.upenn.edu/seligman/ciamanualintro. pdf

Perrone, K.M., Webb, L.K., Wright, S.L., Jackson, Z.V., \& Ksiazak, T.M. (2006). Relationship of spirituality to work and family roles and life satisfaction among gifted adults. Journal of Mental Health Counseling, 28(3), 253-268.

Pryce Jones, J. (2010). Happiness. Retrieved February 2, 2010, from http:/ / en.wikipedia.org/wiki/Happiness_at_work

Ramakrishna, H.V., \& Potosky, D. (2002). Structural shifts in career anchors of Information Systems Personnel: A preliminary empirical analysis. The Journal of Computer Information Systems, 42(2), 83-89.
Raykov, T., \& Marcoulides, G.A. (2000). A first course in structural equation modelling. Mahwah, NJ: Lawrence Erlbaum Associates.

Schein, E.H. (1974). Career anchors and career paths: A panel study of management school graduates. Technical report No. 1. Sloan School of Management, MIT, Cambridge, MA. (ERIC Document Reproduction Service No. ED 099581).

Schein, E.H. (1975). How "career anchors" hold executives to their career paths. Personnel, 52(3), 11-24.

Schein, E.H. (1978). Career dynamics: Matching individual and organizational needs. MA: Addison-Wesley.

Schein, E.H. (1990). Career anchors: Discovering your real values. San Diego, CA: Pfeiffer \& Company.

Schein, E.H. (1996). Career anchors revisited. Implications for career development in the $21^{\text {st }}$ century. Academy of Management Executive, 1, 80-88.

Schimmack, U., \& Oishi, S. (2005). The influence of chronically and temporarily accessible information on life satisfaction judgments. Journal of Personality and Social Psychology, 89, 395-406.

Seligman. M.E.P. (2002). Authentic happiness. New York: Free Press.

Sempane, M.E., Rieger, H.S., \& Roodt, G. (2002). Job satisfaction in relation to organisational culture. SA Journal of Industrial Psychology/SA Tydskrif vir Bedryfsielkunde, 28(2), 23-30.

Sinclair, V. (2009). Career satisfaction. Retrieved February 8, 2009, from http:/ / www.vsinclair.counselling.co.uk/career-e.html

Snyder, C. R., \& Lopez, J. (eds). (2002). Handbook of positive psychology. Washington: APA.

Strasheim, C. (2008). Simultaneous normalisation as an approach to establish equivalence in cross-cultural marketing research. Unpublished PhD thesis, University of Witwatersrand, Johannesburg, South Africa.

Suutari, V., \& Taka, M. (2004). Career anchors of managers with global careers. Journal of Management Development, 23(9), 833-847.

Van Dam, K. (2004). Antecedents and consequences of employability orientation. European Journal of Work and Organisational Psychology, 13(1), 29-51.

Wanous, J.P., Reichers, A.E., \& Hudy, M.J. (1997). Overall job satisfaction: How good are single-item measures? Journal of Applied Psychology, 82, 247-252.

Whitehead, T., \& Kotze, M.E. (2003). Career and life-balance of professional women: A South African study. $S A$ Journal of Human Resource Management/SA Tydskrif vir Menslikehulpbronbestuur, 1(3), 62-76.

Woodd, M. (2000). The move towards a different career pattern: Are women better prepared than men for a modern career? Career Development International, 5(2), 99-105.

Woods, S.A., \& Hampson, S.E. (2005). Measuring the Big Five with single items using a bipolar response scale. European Journal of Personality, 19, 373-390.

Wood, L., Winston, R.B. Jr., \& Polkosnik, M.C. (1985). Career orientations and professional development of young student affairs professionals. Journal of College Student Personnel, 26(6), 533-538. 